\title{
Correlation between fibre content of the lungs and disease in naval dockyard workers
}

\author{
J C WAGNER, C B MONCRIEFF, * R COLES, $†$ D M GRIFFITHS, AND \\ D E MUNDAY
}

From the MRC Pneumoconiosis Unit, Llandough Hospital, Penarth, S Glamorgan, UK

\begin{abstract}
In the period 1966-82 lungs from 333 workers who had been employed at a Royal Naval dockyard were referred to the MRC Pneumoconiosis Unit where they were investigated for the severity of asbestosis, the presence of tumours, and an assessment of mineral fibre content and the type and amount of mineral present. The occupational exposure to mineral dust has been coded for 189 of these cases. There is good correlation between the severity of asbestosis and the coded exposures, electron microscopic mineral fibre count, and the fibre count as seen under the light microscope. The information collected showed that mesotheliomas occurred in those who had had minimal or slight asbestosis, by contrast with the pulmonary carcinomas found in those with moderate to severe asbestosis. The amphibole (crocidolite and amosite) lung content correlated with severity of asbestosis.
\end{abstract}

Since Harries's initial studies in $1966^{1}$ there have been numerous investigations on the effects of exposure to asbestos among the dockyard personnel at Devonport. In the present study details of people in the Plymouth area who died with suspected occupational disease were referred to the coroner and postmortem examinations were undertaken. The lungs were then submitted to the Pneumoconiosis Medical Panel and the material was referred, with the postmortem protocols, to this unit for detailed study. This included a pathological examination for the severity of asbestosis and the diagnosis of any tumour, an assessment of the fibre content and mineral identification of the individual fibres by an analytical transmission electron microscope, and a fibre count undertaken on macerated lung tissue using the Ashcroft technique.

The results from 189 former dockyard workers were compared with their occupational exposure to asbestos.

\section{Materials and methods}

MATERIALS

During the period 1966-81 the lungs from 333

Current addresses:

*National Institute for Agricultural Engineering, Wrest Park, Silsoe, Beds.

†Heatherset, Dark Lane, Modbury, Devon PL21 ORD.

Accepted 9 September 1985 necropsies in the Plymouth area were sent for examination by the Pneumoconiosis Medical Panel to the pathology section of the MRC Pneumoconiosis Unit to establish: (1) the presence or absence of asbestosis and the nature of any associated malignancy, (2) the amount and type of fibre detected in the digested lung by an analytical electron microscope, and (3) the amount of fibre detected in the digested lung by optical microscopy.

Cases had been sent for an assessment of the relevance of asbestos exposure, at the discretion of the Plymouth pathologists, if they had reason to believe that asbestos related disease might have been the main or a contributory cause of death.

\section{Methods}

SPECIMENS

Histological assessment

The methods and techniques used have been standardised as previously described in detail elsewhere. ${ }^{2}$ Asbestosis gradings were therefore assessed using the following criteria.

Minimal asbestosis was present when minimal collagen was seen in the interalveolar septa or around respiratory bronchioles and alveolar ducts together with the presence of asbestos bodies.

Slight asbestosis showed as a definite thickening of the walls of the respiratory bronchioles extending into the alveolar duct again with the presence of asbestos bodies. 
Moderate asbestosis was indicated when the lesions were more profuse and showing some linkage between the lesions.

Marked/severe asbestosis was diagnosed when complete distortion of the normal architecture occurred with large areas of fibrosis, asbestos bodies, and fibres being seen in the distorted air spaces.

\section{Mineral fibre determination by light microscopy}

Light microscope counts were carried out using the method of Ashcroft and Heppleston. ${ }^{3}$ A sample of lung about $1 \mathrm{~cm}^{3}$ was taken from the base of the right lung or, in cases where tumour was present, the least affected lung. This sample was macerated using potassium hydroxide and fibres and bodies in the resulting deposit were counted in a Fuchs Rosenthal counting chamber and examined by phase contrast microscopy using a $40 \times$ objective.

\section{Mineral fibre determination by electron microscopy}

The method used for determining the amount and type of fibre present has been described elsewhere. ${ }^{4}$ Tissue was taken from the least affected lung, but some modifications to the method of selection and preparation of the tissue were made.

Selection of tissue - Centimetre cubes of tissue were taken from three sites: $(a)$ apex of the upper lobe, $(b)$ apex of the lower lobe, and (c) base of the lower lobe. Each of the three pieces was subdivided into two approximately equal parts, and two separate portions

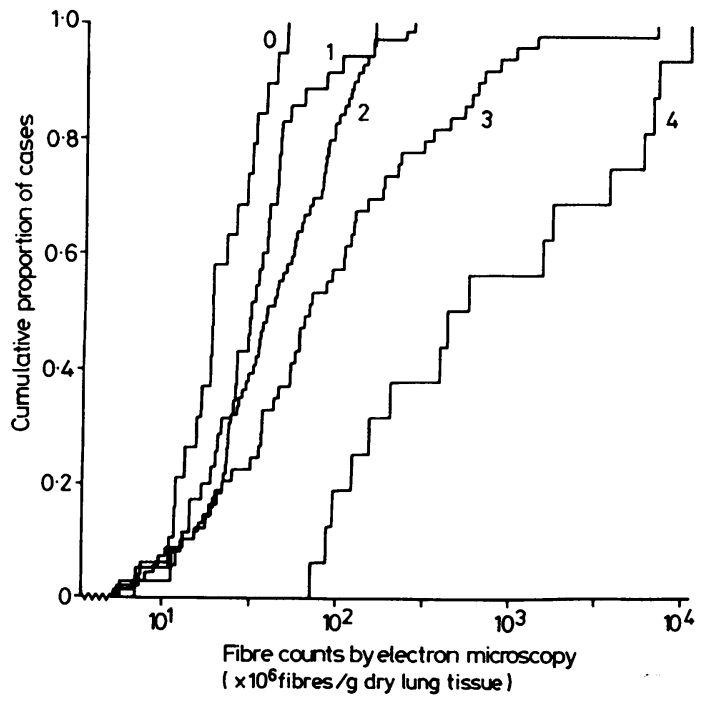

Fig 1 Correlation between pathological grading and electron microscope fibre counts.

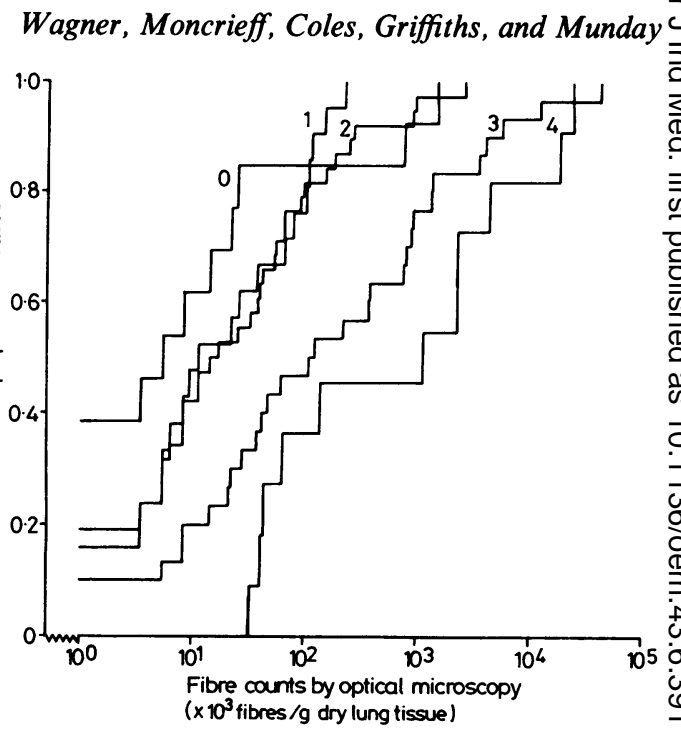

Fig 2 Correlation between pathological grading and optical 윽 microscope fibre counts.

were formed each consisting of a piece from each of the three sites. The weights of the two portions were noted.

Preparation of tissue-Fibre breakage occurs in tissue dried before digestion. To prevent this, one of the portions of wet tissue was digested in $40 \% \mathrm{KOH}$ and $\frac{\mathrm{O}}{\mathrm{O}}$ the subsequent measurements were carried out on the extracted fibres. The other portion was dried to con- $\overrightarrow{0}$ stant weight and the wet to dry tissue ratio calculated.

Occupation and exposure rating

The main dockyard occupation or trade was available in all cases but an exposure score or rating provides a 3 more sensitive assessment of exposure to asbestos. This was derived by allocating an exposure code to each occupation, approximating its severity, andô multiplying the code by the number of years in that job. This method and the codes used have been? described by Rossiter et al in 1983..$^{5}$ An exposure rat- $\rightarrow$ ing was worked out for all dockyard workers with aO complete occupational history and as most of the Plymouth cases were former dockyard workers this. subgroup was used for the first analysis.

Age-The age at death was taken from the clinical ${ }_{\mathscr{E}}^{N}$

notes or death certificate.
Cause of death-The causes of death were divided into the following groups: lung cancer, pleural meso- $\frac{\mathrm{D}}{\mathrm{D}}$ thelioma, other cancer, respiratory disease including $\stackrel{?}{\rightarrow}$ asbestosis, circulatory disease, and all other causes.

A diagnosis of lung cancer or of mesothelioma was recorded only after histological confirmation. 


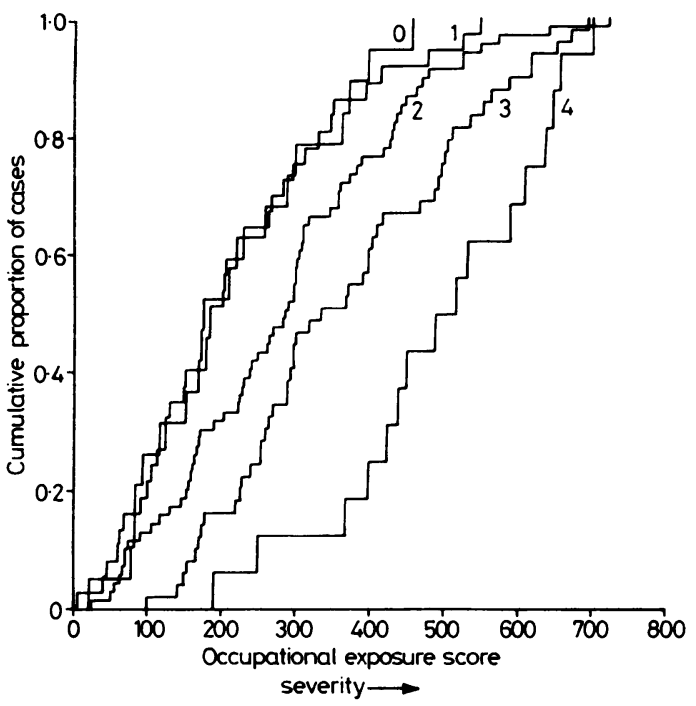

Fig 3 Correlation between pathological grading and occupational exposure score.

\section{Results}

In addition to being former dockyard workers, the criteria for inclusion were known age at death, cause of death, full occupational history, and sufficient lung tissue for fibre analysis.

Cases were excluded from the original 333 for the following reasons: identification problems (4), insufficient tissue for fibre analysis (22), occupation outside the dockyard (48), dockyard workers without full occupational histories (59), reputed dockyard workers not confirmed in records (10), and one woman, leaving 189 in the study group.

The pathological diagnosis of the severity of asbestosis was taken as the basis for the comparison. There is an acceptable correlation between the grades of asbestosis and the amount of fibre found in the lung tissue after maceration using both the electron microscope $^{1}$ and light microscope (figs 1 \& 2), although fine diameter fibre such as chrysotile and some crocidolite asbestos recorded under transmission electron microscopy are not observed using the light microscope.

If such fibres are not present the assessment of the relative amounts of fibre observed by phase contrast microscopy for routine diagnosis may be adequate. In the studies using an electron microscope, however, a more precise assessment will be obtained, particularly when the type of fibre may be defined using EDAX (energy dispersive analysis of $x$ rays). The comparison between the pathological grading and the exposure rating (fig 3) shows good agreement.

Mesothelioma accounted for $39 \%$ of the causes of death, occurring more frequently in the minimal and slight asbestosis grades (table 1). Excepting the nonasbestotic cases, the number of cases with carcinoma of the lung increases with the severity of asbestosis and of exposure, the high number (7 out of 19) of cases of lung cancer among those with no asbestosis was unexpected and cannot be explained. No pattern arises with deaths from general respiratory disease or with the other causes of death. The total amount of fibre was associated with the severity grading of the asbestosis, as was the exposure rating.

The proportional counts of the amphibole fibres crocidolite and amosite increase with the severity of asbestosis, whereas the proportional count, after adjusting for amphibole presence, of chrysotile fibre and also of mullite appears to be unrelated to asbestosis grade (table 2). This agrees with our previous findings. ${ }^{2}$

\section{Discussion}

As illustrated in the figures, the relations between the severity of the lung pathology, the occupational exposure rating, and the fibre content of the lungs are

Table 1 Lung pathology related to age, exposure to asbestos, cause of death, and fibrous dust content in 189 cases from the Plymouth area (all male)

\begin{tabular}{|c|c|c|c|c|c|c|c|c|c|c|}
\hline \multirow{2}{*}{$\begin{array}{l}\text { Grade of } \\
\text { asbestosis } \\
(J C W)\end{array}$} & \multirow{2}{*}{$\begin{array}{l}\text { Total } \\
\text { No of } \\
\text { cases }\end{array}$} & \multirow{2}{*}{$\begin{array}{l}\text { Mean } \\
\text { age } \\
\text { at } \\
\text { death }\end{array}$} & \multirow{2}{*}{$\begin{array}{l}\text { Mean } \\
\text { exposure } \\
\text { rating }\end{array}$} & \multicolumn{6}{|c|}{ No $(\%)$ (cause of death) } & \multirow{2}{*}{$\begin{array}{l}\text { Mean } \\
\text { fibre } \\
\text { count } \\
\left(\times 10^{6}\right)\end{array}$} \\
\hline & & & & $\begin{array}{l}\text { Lung } \\
\text { cancer }\end{array}$ & $\begin{array}{l}\text { Pleural } \\
\text { mesothelioma }\end{array}$ & $\begin{array}{l}\text { Other } \\
\text { cancer }\end{array}$ & $\begin{array}{l}\text { Respiratory } \\
\text { disease }\end{array}$ & $\begin{array}{l}\text { Circulatory } \\
\text { disease }\end{array}$ & $\begin{array}{l}\text { Other } \\
\text { causes }\end{array}$ & \\
\hline $\begin{array}{l}\text { None } \\
\text { Minimal } \\
\text { Slight } \\
\text { Moderate } \\
\text { Marked/ }\end{array}$ & $\begin{array}{l}19 \\
36 \\
69 \\
49\end{array}$ & $\begin{array}{l}66 \\
64 \\
63 \\
64\end{array}$ & $\begin{array}{l}212 \\
219 \\
286 \\
368\end{array}$ & $\begin{array}{r}7(37 \%) \\
3(8 \%) \\
9(13 \%) \\
17(35 \%)\end{array}$ & $\begin{array}{r}3(16 \%) \\
24(67 \%) \\
35(51 \%) \\
11(22 \%)\end{array}$ & $\begin{array}{l}0(0 \%) \\
2(6 \%) \\
1(1 \%) \\
2(4 \%)\end{array}$ & $\begin{array}{r}6(32 \%) \\
0(0 \%) \\
9(13 \%) \\
10(20 \%)\end{array}$ & $\begin{array}{r}2(11 \%) \\
7(19 \%) \\
14(20 \%) \\
7(14 \%)\end{array}$ & $\begin{array}{l}1(5 \%) \\
0(0 \%) \\
1(1 \%) \\
2(4 \%)\end{array}$ & $\begin{array}{r}23 \cdot 0 \\
42 \cdot 1 \\
59 \cdot 5 \\
343 \cdot 2\end{array}$ \\
\hline severe & 16 & 64 & 495 & $13(81 \%)$ & $1(6 \%)$ & $0(0 \%)$ & $2(13 \%)$ & $0(0 \%)$ & $0(0 \%)$ & $2550 \cdot 3$ \\
\hline All grades & 189 & 64 & 305 & $49(26 \%)$ & $74(39 \%)$ & $5(3 \%)$ & $27(14 \%)$ & $30(16 \%)$ & $4(2 \%)$ & 336.9 \\
\hline
\end{tabular}


Table 2 Mineral content of Plymouth cases by electron microscopy

\begin{tabular}{|c|c|c|c|c|c|c|c|c|c|c|c|}
\hline \multirow{3}{*}{$\begin{array}{l}\text { Grade of } \\
\text { asbestosis } \\
(J C W)\end{array}$} & \multirow{3}{*}{$\begin{array}{l}\text { Total } \\
\text { No of } \\
\text { cases }\end{array}$} & \multirow{3}{*}{$\begin{array}{l}\text { Mean } \\
\text { exposure } \\
\text { rating }\end{array}$} & \multirow{3}{*}{$\begin{array}{l}\text { Mean } \\
\text { fibre } \\
\text { count } \\
\left(\times 10^{6}\right) \\
(E M)\end{array}$} & \multicolumn{5}{|c|}{ Mean $\%$ constitution } & \multirow{2}{*}{\multicolumn{3}{|c|}{$\begin{array}{l}\text { Mean } \% \text { constitution after exclusion } \\
\text { of amosite and crocidolite }\end{array}$}} \\
\hline & & & & Amo & Cro & Chr & Mul & Others & & & \\
\hline & & & & & & & & & $C h r$ & Mul & Others \\
\hline \multirow{2}{*}{$\begin{array}{l}\text { None } \\
\text { Minimal } \\
\text { Slight } \\
\text { Moderate } \\
\text { Marked/ } \\
\quad \text { severe }\end{array}$} & $\begin{array}{l}19 \\
36 \\
69 \\
49\end{array}$ & $\begin{array}{l}212 \\
219 \\
286 \\
368\end{array}$ & $\begin{array}{r}23 \cdot 0 \\
42 \cdot 1 \\
59 \cdot 5 \\
343 \cdot 2\end{array}$ & $\begin{array}{r}6 \% \\
6 \% \\
16 \% \\
28 \%\end{array}$ & $\begin{array}{l}11 \% \\
25 \% \\
36 \% \\
36 \%\end{array}$ & $\begin{array}{l}39 \% \\
36 \% \\
24 \% \\
17 \%\end{array}$ & $\begin{array}{l}34 \% \\
24 \% \\
17 \% \\
14 \%\end{array}$ & $\begin{array}{r}11 \% \\
10 \% \\
7 \% \\
4 \%\end{array}$ & $\begin{array}{l}46 \% \\
50 \% \\
48 \% \\
52 \%\end{array}$ & $\begin{array}{l}41 \% \\
36 \% \\
38 \% \\
34 \%\end{array}$ & $\begin{array}{l}13 \% \\
14 \% \\
14 \% \\
14 \%\end{array}$ \\
\hline & 16 & 495 & $2550 \cdot 3$ & $33 \%$ & $52 \%$ & $7 \%$ & $5 \%$ & $2 \%$ & $43 \%$ & $31 \%$ & $26 \%$ \\
\hline All grades & 189 & 305 & $336 \cdot 9$ & $17 \%$ & $33 \%$ & $25 \%$ & $18 \%$ & $7 \%$ & $49 \%$ & $36 \%$ & $15 \%$ \\
\hline
\end{tabular}

Amo = Amosite.

Cro = Crocidolite

Chr = Chrysotile.

Mul = Mullite.

good. The counts obtained from the electron microscope methods are in agreement with those we have presented verbally.

The counts under the light microscope are given in the $\times 10^{3}$ range as compared with $\times 10^{6}$ of those recorded by Whitwell ${ }^{6}$ but are consistent with those found by Seal. ${ }^{7}$ The fibre content found in the cases with no evidence of asbestosis was higher than would be expected in the lungs of members of the general public but it must be remembered that the people had been occupationally exposed.

The mineral content of the lungs confirmed our previous findings. ${ }^{2}$ The amphibole fibre (crocidolite and amosite) amounts increased with the severity of the asbestosis and occupational exposure, but the chrysotile remained constant. This was clearly illustrated in table 3 where the mineral fibre content was considered after the exclusion of the two amphibole fibres. A detailed fibre length analysis was undertaken on a sample of the cases but did not provide any relevant information.

When comparing the associations with lung cancer and mesothelioma, it may be seen that the mesotheliomas occur mostly with a minimal or slight asbestosis grading and a low exposure rating. The lung cancers occur with the moderate to severe grades with heavier exposures, although these mainly had pleural or other lung disease.

\section{Conclusion}

We have shown that the severity of the various diseases associated with exposure to asbestos dust may be correlated with the amphibole fibre content of the lungs and the occupational exposure ratings. The chrysotile does not increase with the severity of the thoracic lesions.

For the general pathological assessment the Ashcroft technique may be adequate; there is little advantage in elaborating on this technique. Most histopathologists will undertake the least time consuming method and it would be wise to establish this method as the standard. It is not thought that the variations in the counts that will occur in different laboratories will upset the broad range of fibre content which would indicate that the patient had been exposed to asbestos dust. This technique, however, fails to detect low quantities of chrysotile and other fine fibres.

For research purposes, however, it is essential to have a full assessment of the type of fibre and amount of each type of fibre. For this an analytical transmission electron microscope is required.

We are most grateful for the tolerance, patience, and typing skills of Mrs Rosemary Hill.

Table 3 Mineral content of Plymouth cases by light microscopy

\begin{tabular}{llllr}
\hline $\begin{array}{l}\text { Grade of asbestosis } \\
(J C W)\end{array}$ & $\begin{array}{l}\text { Total No of } \\
\text { cases }\end{array}$ & $\begin{array}{l}\text { Mean exposure } \\
\text { rating }\end{array}$ & $\begin{array}{l}\text { Mean fibre count } \\
\left(\times 10^{3}\right)(L M)\end{array}$ & $\begin{array}{l}\text { Mean fibre count } \\
\left(\times 10^{6}\right)(E M \text { for LM cases })\end{array}$ \\
\hline None & 13 & 212 & 189 & $24 \cdot 7$ \\
Minimal & 21 & 219 & 48 & 33.7 \\
Slight & 38 & 286 & 167 & 55.9 \\
Moderate & 30 & 368 & 2747 & 235.9 \\
Marked/severe & 11 & 495 & 5199 & 2731.9 \\
All grades & 113 & 305 & 1322 & 356.4 \\
\hline
\end{tabular}




\section{References}

${ }^{1}$ Harries PG. Asbestos hazards in naval dockyards. Ann Occup Hyg 1968;11:135-45.

${ }^{2}$ Wagner JC, Pooley FD, Berry G, et al. A pathological and mineralogical study of asbestos-related deaths in the United Kingdom in 1977. Ann Occup Hyg 1982;26:423-31.

${ }^{3}$ Ashcroft T, Heppleston AG. The optical and electron microscopic determination of pulmonary asbestos fibre concentration and its relation to the human pathological reaction. J Clin Pathol 1973;26:224-34.

${ }^{4}$ Pooley FD. The identification of asbestos dust with an electron microscope analyser. Ann Occup Hyg 1975;18:181-6.

${ }^{5}$ Rossiter CE, Coles RM, Jackaman I. HM Naval Base, Devonport: lung cancer and mesothelioma case control studies. In: Proceedings of the VIth international pneumoconiosis conference, Bochum, 20-23 September, 1983. Vol 2. Geneva: International Labour Office, 1984:830-6.

${ }^{6}$ Whitwell F, Scott J, Grimshaw M. Relationship between occupations and asbestos fibre content of the lungs in patients with pleural mesothelioma, lung cancer, and other diseases. Thorax 1977;32:377-86.

${ }^{7}$ Seal RME. Current views on pathological aspects of asbestosis (the unresolved questions and problems). In: Wagner JC, Davis W, eds. Biological effects of mineral fibres. Vol 1. WHO/IARC symposium, Lyon, 1979. Lyon: International Agency for Research on Cancer, 1980:217-35. (IARC sci pub No 30, INSERM symposia series vol 92 .)

\section{Correspondence and editorials}

The British Journal of Industrial Medicine welcomes correspondence relating to any of the material appearing in the journal. Results from preliminary or small scale studies may also be published in the correspondence column if this seems appropriate. Letters should be not more than 500 words in length and contain a minimum of references. Tables and figures should be kept to an absolute minimum. Letters are accepted on the understanding that they may be subject to editorial revision and shortening.

The journal now also publishes editorials which are normally specially commissioned. The Editor welcomes suggestions regarding suitable topics; those wishing to submit an editorial, however, should do so.only after discussion with the Editor. 